\title{
CHLOROCRUOROPORPHYRIN: A SIMPLE METHOD OF PREPARATION
}

\author{
By Gilbert Y. Kennedy \\ Cancer Research Laboratory, University Field Laboratories, Lodge Moor, Sheffield ro
}

Munro Fox (1926, Addendum, p. 219) described a method of preparation of chlorocruoroporphyrin from the blood of the marine polychaete worm Spirographis. This was based upon the very troublesome method of Nencki \& Zaleski (1900), which is time-consuming and wasteful. Furthermore, Spirographis is not easily obtainable in this country. Lemberg \& Parker (I952) started with protoporphyrin, and by careful oxidation with potassium permanganate in acetone obtained a solution which gave mixed crystals of chlorocruoroporphyrin and diformyldeuteroporphyrin esters. Purification was by fractional chromatography. The procedure to be described here is simple and rapid, and could easily be carried out in one day by a biologist requiring a small sample of the porphyrin. The two methods mentioned above would not come into this category.

This work was done at the Plymouth Laboratory, and I am very grateful to $\mathrm{Mr}$ T. R. Tozer of that laboratory for so kindly obtaining the animals for me and extracting the blood.

The polychaete worms Myxicola infundibulum, Sabella pavonina and Branchiomma vesiculosum are all readily obtained from the muddy shores of the Salcombe estuary, especially on the Salstone. Blood was taken directly from the vessels of about Ioo assorted worms by syringe, and squirted as it was removed from the worms into a mixture of peroxide-free ether (3 parts) and 'Analar' glacial acetic acid (I part). After all the blood had been added, the mixture was well shaken and allowed to stand in the ice-chest for $30 \mathrm{~min}$. The acetic acid was then washed out with distilled water, the first few washings containing a little sodium acetate to avoid washing out of the pigment, and the remaining solution of chlorocruorohaematin dried roughly by filtering through ether-soaked paper into a distilling flask and evaporated to dryness. $100 \mathrm{ml}$. of a $50 \%$ solution of hydrazine hydrate in glacial acetic acid were then added, and the mixture heated on a water-bath at $90^{\circ} \mathrm{C}$. for Io min. During that time, the chlorocruorohaematin dissolved, and the solution became violet-red and red-fluorescent to ultra-violet light, indicating the formation of the free porphyrin. When cool, the solution was poured into a large separating funnel with $300 \mathrm{ml}$. peroxide-free ether, and the flask rinsed out with ether, the rinsings being added to the funnel. The acid and hydrazine hydrate were then washed out with distilled water, the first washings containing sodium acetate as before, and the ether solution of the porphyrin 
shaken with $\mathrm{Io} \mathrm{ml}$. lots of $5 \%$ (w/v) $\mathrm{HCl}$ ( $137 \mathrm{ml}$. conc. $\mathrm{HCl} / \mathrm{l}$.) until no more of the lower layers were fluorescent. The pooled acid extracts were then added to ether in a separating funnel, and the porphyrin driven back into ether by the addition of saturated sodium acetate solution-just red to Congo Red paper in the lower layer. The ether solution was washed with distilled water to remove salts and acetic acid, and dried by the usual method of filtering through ether-soaked paper. The ether was then distilled off on the water-bath to a volume of about $25 \mathrm{ml}$., and the remainder evaporated in a dish to dryness. The residue was dissolved in the minimum amount of dry chloroform and when hot, the porphyrin precipitated by the addition of light petroleum, B.P. $40-60^{\circ} \mathrm{C}$. This is quicker than the crystallization method, but does not give so fine a product. The precipitate was centrifuged down and washed with petroleum ether, and dried in the incubator. Yield, $22 \mathrm{mg}$.

Absorption spectra were measured with the Hartridge Reversion Spectroscope:

$\begin{array}{lcccc}\text { Chlorocruoroporphyrin } & \text { I } & \text { II } & \text { III } & \text { IV } \\ \text { In pyridine }(\mathrm{m} \mu) & 645 & 57 \mathrm{I} & 553 & 5 \mathrm{I} 7 \\ & & \text { I } & \text { II } & \\ \text { In } 5 \%(\mathrm{w} / \mathrm{v}) \mathrm{HCl}(\mathrm{m} \mu) & & 6 \mathrm{I} 5 & 556 & \end{array}$

\section{REFERENCES}

Fox, H. Munro, 1926. Chlorocruorin: a pigment allied to haemoglobin. Proc. Roy. Soc., B, Vol. 99, pp. 199-220.

Lemberg, R. \& Parker, J., I952. Porphyrins with formyl groups. II. Preparation of chlorocruoroporphyrin and diformyl deuteroporphyrin. Austral. F. Exp. Biol. Med. Sci., Vol. 30, pp. 163-70.

NenCKI, M. \& Zaleski, J., 1900. Untersuchungen über den Blutfarbstoff. Z. physiol. Chem., Bd. 30, 384 pp. 